\title{
TRAINING OF FUTURE AIRCRAFT MAINTENANCE ENGINEERS FOR IMPROVING PROFESSIONAL COMMUNICATION
}

\author{
Iuliia Mazurenko \\ Postgraduate Student, Flight Academy of the National Aviation University, Ukraine \\ e-mail: mazurenko84@bigmir.net,orcid.org/0000-0002-8384-8933
}

\section{Summary}

The aim of the paper is to study the problem of future aircraft maintenance engineers' training for improving professional communication. Higher aviation educational institutions ensure that graduates master communication skills and acquire communication competencies that allow them to solve typical tasks of their work. Due to internalization and globalization of aviation sphere, communication in the international airports is carried out in English. However, the level of English proficiency of future aircraft maintenance engineers is not sufficient to communicate effectively while performing professional tasks. To solve the problem the pedagogical conditions of future aircraft maintenance engineers' training for improving professional communication are suggested (enhancing motivation to communicate through active interaction and creating situations of success in the classroom; modeling professional communicative situations to ensure the practical orientation of training; use of technological innovations for self-analysis and self-education). The defined pedagogical conditions are implemented through specially chosen methods: interactive (ice-breaking, warming up activities, training exercises, etc.), case study, role playing, ICT (based on Learning Management Systems MOODLE).

Keywords: pedagogical conditions, readiness for professional communication, professional activity, future aviation maintenance engineers, aviation specialists.

\section{DOI: https://doi.org/10.23856/4609}

\section{Introduction}

Aviation in Ukraine has been actively developing: new airlines are constantly appearing, and their fleet is expanding. As a result, there is a need to train high-quality specialists for aircraft maintenance who perform this job for airlines. Ukraine is one of few countries in the world with a full cycle of aircraft development and it occupies a leading position in the world market in the sector of development and production of transport and passenger aircraft. This industry requires qualified specialists to satisfy its needs.

Higher aviation educational institutions ensure that graduates master the system of skills and acquire appropriate competencies that allow them to solve typical tasks of their work. According to the Ukrainian state education standard of the specialty «Air Transport» one of the main competencies is English proficiency.

The legislative and regulatory documents, in particular the laws of Ukraine «On Education», «On Higher Education»; ICAO standards and recommended practices; recommendations of the European Organization for the Safety of Air Navigation (Eurocontrol); ICAO Circulars № 323-An / 185 «Recommendations for Aviation English Language Training Programs»; ICAO documents № 9835 An / 453 «Guide to the implementation of ICAO language proficiency 
requirements» highlight the importance of professional communication in aviation. Pilots, air traffic controllers and aviation engineers work in the international environment, which requires special attention to linguistic factor.

Due to internalization and globalization of aviation sphere, communication is carried out in English. The aircraft maintenance engineers use English while communicating with pilots of international flights, organizing aircraft maintenance and testing in multinational team, working with technical documents and manuals, filing reports, socializing in international aviation companies, going to business trips abroad, interaction with foreign colleagues. Therefore, knowledge of English is considered to be a mandatory component of professional future aviation engineers' training. However, the reality demonstrates the lack of professional communication skills of future aircraft maintenance engineers. As a result, they are not ready to work in the multicultural professional environment. The analyses of the surveys of working aviation engineers revealed difficulties during communication in English with pilots of international airlines, with foreign colleagues on business trips, during advanced training abroad, making reports and other technical documents.

The problem of training aviation specialists for professional communication was the object of research made by O. Vasiukovych, E. Kmyta, O. Kovtun, O. Moskalenko, H. Pashchenko, S. Tymchenko, I. Fainman and others. The researchers (L. Baranovska, N. Glushanytsia, O. Hnatiuk, A. Kokareva, E. Luzik, O. Kaverina, L. Konoplianyk, O. Panchenko, and others) devoted their works to the problems of future aviation engineers' professional training. At the same time, the issue of future aircraft maintenance engineers' training for improving professional communication has not been the subject of scientific research.

\section{Defining pedagogical conditions of future aircraft maintenance engineers' training for improving professional communication}

The purpose of higher education is to train a highly qualified competent specialist capable of solving complex professional problems. The education sector is under the process of constant reformation to ensure this goal, to find new ways and means to improve training. Aviation specialists are not the exception due to increasing international requirements and demands from employers. There is a need to identify the factors and possibilities of education content, which is an effective tool for modeling professional training. Substantiation and implementation of effective pedagogical conditions will increase the level of professional communication of future aircraft maintenance engineers. In this study, we interpret pedagogical conditions as a set of interrelated and interdependent circumstances that affect the organization of the pedagogical process and contribute to the effectiveness of future aircraft maintenance engineers' training for the formation of all components of professional communication.

The analysis of the theoretical foundations of the problem under consideration, interviews and surveys of specialists in the aviation industry, teachers of aviation education establishments allowed determining the following pedagogical conditions, the impact of which will most effectively affect the process of readiness for professional communication:

- enhancing motivation to communicate through active interaction and creating situations of success in the classroom;

- modeling professional communicative situations to ensure the practical orientation of training;

- use of technological innovations for self-analysis and self-education. 


\section{Enhancing motivation to communicate through active interaction and creating situations of success in the classroom}

The first pedagogical condition - enhancing motivation to communicate through active interaction and creating situations of success in the classroom - emphasizes the role of motivation for forming communicative competence. I. Zimnyaya (Zimnyaya, 1991: 100) states that motivation is a set of different irritators (needs, motives, feelings, interests, etc.); it determines, stimulates, and encourages a person to perform an action that is included in the activities defined by this motivation.

The positive atmosphere in the process of language acquisition is identified among the factors, which influence the formation of motivation to learning. In particular, A. Shchukin (Shchukin, 2004: 24) mentions the additional factors motivating to learn the language. These are the attractiveness of the material, the nature of methods, psychological environment and the teacher's ability to find an individual approach, subjective characteristics of students, skills and willingness to learn, teacher's personal traits. L. Podoliak and V. Yurchenko (Podoliak, Yurchenko, 2008: 164) note that the formation of learning motives is possible only in the activities organized by the teacher. In their opinion, to ensure a stable motivational sphere it is necessary to do the following: to enrich the content of educational material; to highlight the social significance of future professional activity; form an idea of future professional life; to help to understand the short and final learning goals, the importance of self-study; to assist with analyses of the literature; to maintain the psychological climate in the study group; to cultivate a responsible attitude to learning.

Interactive learning is a contributing factor to language learning. It is interpreted by T. Rozumna (Rozumna, 2012: 5) as 'subject-subject interaction based on the dialogue of a teacher with students and students with each other, which is built on the principles of cooperation and involves the uniqueness of participants and their equality, variability of each person's position on perception, understanding and active interpretation of other people's opinions'. The researcher proves that to provide such interaction there should be the following factors: presence of positive relationships between the participants; cooperation; reliance on student's personal experience; inclusion of 'bright' examples and facts in the educational process; availability of various forms of student activity and their regular change; inclusion of internal and external motivation; mutual motivation of students.

Interaction in the classroom appears when the teachers are motivated, because they set up positive and friendly relationships with students. In the classroom the teacher maintains motivation for communication through the use of interesting material, cooperation and use of experiences, which stimulate mutual motivation on the part of students. N. Navolokova (Navolokova, 2009), the researcher of effective pedagogical technologies and innovations, notes that the formation of deep internal motivation is one of the aims and objectives of interactive learning, so this fact proves the significant impact of interaction on student's motivation.

O. Pometun notes that 'without the opportunity to discuss, ask questions, study and even teach others, real learning does not happen' (Pometun, 2007: 15). In such training, the teacher is a facilitator, and interpersonal communication and cooperation help to achieve optimal learning outcomes. Interaction helps to prepare students for professional communication, in the process of mutual problem solving and discussion the students are engaging in professional development.

Creating situations of success is important for motivating future aircraft maintenance engineers, because it is aimed at involving the 'motive of achievement'. According to 
S. Zaniuk (Zaniuk, 2002), success from activity depends not only on ability, knowledge, skills and abilities, but also on motivation to achieve. A person with a high level of motivation to achieve works harder, tries to get higher results, purposefully achieves goals. The extent of a person's motivation is measured by the influence of the following factors: the importance of success, hope for success, subjectively assessed probability of success, subjective standards of achievement. Among the main factors interfering communication are the fear of being underestimated and peers' disapproval. Reducing the motives for failure and motivation to achieve success ensure the effectiveness of training in future aircraft maintenance engineers' professional communication.

The methods that are used for creating friendly atmosphere in the classroom are taken from training method. There are different ice-breaking and warming up activities, training exercises. The example of these methods can be the exercise 'Chair of success'. It is aimed at improving a positive perception of future, development of self-confidence and motivation. In the center of the audience there is a magical 'chair of success'. The teacher explains that the one who sits in it becomes a successful, self-confident person. The player sits down in a chair and talks about his future, about his profession, about his life success, how he came to it. This student says: "I am a successful person, I do my favorite things. I am confident in my abilities, my dreams come true, my plans come true. I am happy, I am open to development, my life is how I create it". Believing in abilities and success projects the student's behavior.

\section{Modeling professional communicative situations to ensure the practical orientation of training}

The second pedagogical condition for future aircraft maintenance engineers' training for professional communication - modeling professional communication situations to ensure the practical orientation of training - is mainly connected with applying activity and contextual approaches in the pedagogical process. The essence of the activity approach lies in the fundamental role of activity in human life: the personality does not only come out in the activity, but also is formed. The contextual approach involves 'immersion' in professional activities in the learning process. The researcher A. Verbitskiy defines contextual learning as 'where the subject and social content of the future professional activity is modeled, and the mastering abstract knowledge as sign systems is placed on the canvas of this activity' (Verbitskiy, 1991: 33). At the core of contextual learning there is a problem situation that motivates to focus on knowledge to solve the problem. The subject and social modeling of future professional activity is done through active teaching methods.

O. Tarnopolskyi emphasizes that in teaching foreign language speaking the priority should be given to the communicative approach, because it "creates the conditions that are as close as to the real conditions of foreign language communication and models them' (Tarnapolskyi, 2006: 243). In the center of communicative approach is a problem situation. The professional communicative situation is the initial factor of communication, which motivates the specialist to interaction in the professional environment. The linguist $F$. Batsevych interprets a communicative situation as 'a specific communicative situation, which includes communication partners and which encourages its participants to interpersonal interaction' (Batsevych, 2004: 337).

Researcher O. Bernadska (Bernadska, 2004) notes the advantages of modeling professional communicative situations in developing foreign language communication skills, namely: the presence of novelty elements, creativity; way to get rid of monotony; creating an 
atmosphere of communication during the lesson; improving the quality of foreign language teaching. The scientist offers stages of pedagogical modeling of professional situations: problem statement, model construction of a certain pedagogical situation, choosing a way of its application, realization of the model in educational process, analysis of the received results. O. Bernadska gives the classification of professional communicative situations types: situation-exercise, situation-illustration, situations-assessment, situations-request for information, situation-presentation, and situation-problem. The experimental study of implementing the system of professional situations demonstrates the intensification of the learning process and thus promotes the formation of communication skills.

L. Yakubovska (Yakubovska, 2002) experimentally proves that applying educational role-playing games of professional orientation in the process of learning a foreign language helps to solve a range of important tasks effectively: intensification of the learning process, giving it a creative character; acquisition of communication experience in foreign language in the context of the future profession; development cognitive and professional motives; formation of a holistic view of future professional activity, its specifics and functions; improvement of communicative skills and abilities of social interaction, individual and collective decision-making; increasing the academic performance.

A. Dranko (Dranko, 2016) also proves the effectiveness of modeling communicative situations in the formation of the future aviation professionals' readiness for professional interaction. In the pedagogical experiment the following results were obtained: in the experimental group $54 \%$ of cadets were with a high level of professional interaction during training in comparison with the control group with the result $-35 \%$.

Aviation is a progressive, rapidly changing and innovative industry. The teachers involved in the educational process of flight schools must constantly improve and keep up with the scientific and technical process. It is natural for technical specialties, however, for an English teacher such tendency is a challenge and it leads to insufficient practical orientation of English for specific purposes. There are difficulties in filling the course content for aviation professionals with case studies, problem situations and real examples. This is especially challenging in institutions where cooperation between departments is more formal, as the teachers are limited by the lack of knowledge in technical subjects. To solve the existed problem higher educational establishments need to use the potential of aviation departments for designing professional and communicative situations for professional communication skills.

The subject matter of professional communication situations for future mechanical engineers is based on their professional responsibilities. We have identified the main areas of professional and communicative situations: 1) communicative support of technical processes of aircraft maintenance and repair; 2) interaction with other services on professional issues; 3) business trips abroad to other airports on professional issues; 4) communication about technical documentation in English.

The case study method is one of the best how to use professional and communicative situations for improving communication skills. The students are given cards describing professional situations and asked to work in groups to discuss them. The cards include reports from Aviation Safety Reporting System. For example, Card 1. ASRS Report No. 863354 (material taken from Fisher, 2016):

"During the preflight inspection I [pilot] noticed fluid underneath the number two engine cowling in the vicinity of the drain mast. Upon finishing the aircraft inspection I briefed the Captain and called Maintenance from the jetway telephone....I also showed the Captain three digital photos I had taken of the leak. 
The Captain then called Maintenance and asked that the mechanic (who signed off the write-up) return to the aircraft. When the mechanic returned, the Captain requested I show the mechanic the leak so that we were all on the same page.... When we got to the engine I showed him the fresh fluid on the ground and also wiped a sample off the bottom of the cowling (he never bothered to bend down to look at the underside of the engine). He tried to convince me that this was normal. I told him that I disagreed and he said, 'Well, I already signed it off!'

As I returned to the aircraft he continued to lecture me about how fluid coming off the engine was normal. At one point he tried to pass off the fluid as an overservice of engine oil. The mechanic continued to lecture me, at times raising his voice, as we made our way up the jetway. He was very argumentative. In the cockpit he continued to interrupt me as I tried to advocate to the Captain my point of view. At one point he became very agitated and said that fluid leaking from the bottom of engines is normal and that this was just like the DC-8, 727, etc. He also said that if we want he can pull everyone off the airplane, delay the flight for over an hour, open up the cowling, and run the engine. Then he pointedly said, 'but, I will tell you right now, I won't find anything!' The discussion continued for some time which resulted in a pilot delay".

The students answer the questions:

1 . What is the problem in the case?

2. Why do you think this situation occurred?

3 . What are the possible solutions of this problem?

4. How would you behave being an aircraft engineer?

Thus, modeling professional and communicative situations in future aircraft maintenance engineers' training will ensure the practical orientation of the subject, improve the process of acquiring professional communication skills, and increase motivation to communicate.

\section{Use of technological innovations for self-analysis and self-education}

We have defined the third pedagogical condition of future aircraft maintenance engineers' training for professional communication as the use of technological innovations for self-analysis and self-education. The role of information and communication technologies (ICT) in education is difficult to overestimate today. A. Andreev (Andreev, 2002) notes that the society informatization is an important feature of the modern stage of development. Since the 70 s of the last century, the process of society informatization has become global and has covered not only affluent countries but also developing ones.

Self-analysis is a contributing factor for the formation of a reflective attitude to professional activity. It helps to understand the personal inner world and activity, to compare expectations and results, to identify features and qualities for further detailed study. L. Terletska characterizes self-analysis as 'a difficult, gradual process, sometimes painful and unpleasant, requiring all available constructive energy' (Terletska, 2012: 153). The researcher notes that attempts at constructive self-analysis are of great importance as they provide an opportunity for self-realization. As a result of self-analysis the self-esteem is formed, which is 'a person's judgment about the degree of presence of certain qualities, properties in comparison with a certain standard, sample' (Terletska, 2012: 155). Self-analysis is the main structural component of self-identity, which plays an important role in self-regulation. Thus, in the process of developing professional communication, self-analysis helps to move forward, correct existing drawbacks and continuous self-improvement.

The process of communication is constantly changing, so communicative competence is improving throughout life. This is especially necessary in the field of foreign language 
communication. Self-development of future aircraft maintenance engineers' communicative competence includes continuous vocabulary expansion, improving grammar skills, active listening and speaking, the result of which is self-education, which is reflected in mastering knowledge from various sources and using them in professional communication.

The main resources of English professional communication for aircraft maintenance engineers can be the following: aviation books, operating instructions, aviation documentation, professional periodicals (aviation newspapers, magazines); Internet; television programs; video, audio information (podcasts, YouTube channels); webinars, online classes, workshops; various courses; excursions; travelling abroad. Of course, some resources are beyond the influence of a teacher, such as travelling abroad and foreign excursions, however, the teacher has an opportunity to motivate students to such activities, talking about their impact on the development of English professional communication.

The characteristic features of professional communication training with the use of ICT are constant increase of information, the presence of a wide range of technological innovations, rapid change of technology and their obsolescence. The role of self-study with the use of ICT is highlighted by the number of scientists (Andreev, 2002; Kyselova 2011; Plachynda et al., 2019; Tyshchenko, 2016). O. Tyshchenko emphasizes the role of self-education in professional training and notes that 'self-education is the result of education and a prerequisite for the effectiveness of the latter' (Tyshchenko, 2016: 161). The researcher notes that education and self-education are interconnected due to several factors: 1) self-education contributes to the accumulation of knowledge, the formation of intelligence, the development of mental strength and abilities; 2) self-education is an informative process, a component of mental self-education, which produces the qualities necessary for successful knowledge acquisition; 3) self-education is not the same as self-study, because self-education is a purposeful voluntary improvement of personality through self-study.

O. Kyselova defined the features of self-education in the modern information and educational environment, which are at the same time the advantages of their use in the future aircraft maintenance engineers' training (Kyselova, 2011: 7): openness and dynamism of self-education information space; expansion of self-education forms; absence of time and territorial restrictions on its implementation; variability of self-educational electronic educational and information resources; indirect access to Internet sources; availability of additional opportunities for self-control.

Curricula for future aircraft maintenance engineers provide a significant number of hours to self-study. Higher education is still looking for ways to organize self-study effectively. The researchers of aviation specialists' training by means of ICT (Plachynda et al., 2019) note that up to $60 \%$ of the time was allocated for independent work in aviation specialists' training. Analyzing the theoretical frameworks on ICT for self-study and the fact that students actively use gadgets in everyday life, they proposed the use of MOODLE system for self-study and experimentally proved its effectiveness. Among the advantages of using the platform are the following: reliance on students' IT habits; access to information 24/7; convenient structuring of material; ease of evaluation; ease of updating material and editing; ease of task planning; use of audio and video materials; automated student rating system; self-check; psychological and physiological comfort; objective assessment (without human error), etc. The negative aspects of the implementation of the MOODLE platform are the following: time-consuming technology of placement of educational materials; inability to identify the person performing the task (the ability to perform tasks for a friend); lack of self-discipline in students; temporary lack of access to the resource due to technical problems; loss of communication; non-socialization and 
lack of public speaking skills; the difficulty of training teachers to use the web-based platform MOODLE, etc.

For future aircraft maintenance engineers we suggest using Learning Management Systems (LMS) MOODLE where they can find all necessary resources for self-development and self-study. The material is organized according to the curriculum including tests for self-analysis, links to video and audio recourses, vocabulary lists, additional exercises, etc.

\section{Conclusions}

Thus, we have identified the pedagogical conditions for the formation of future aircraft maintenance engineers' professional communication training, namely: enhancing motivation to communicate through active interaction and creating situations of success in the classroom; modeling professional communicative situations to ensure the practical orientation of training; use of technological innovations for self-analysis and self-education. The selected conditions are closely interrelated and affect other components of the structural and functional model of training future aircraft maintenance engineers for professional communication. Further research is seen in experimental verification of the proposed conditions.

\section{References}

Andreev A. A. (2002) Pedagogika vysshey shkoly. Novyy kurs [Higher school pedagogy. New course]. M.: Moskovskiy mezhdunarodnyy institut ekonometriki, informatiki, finansov i prava. [in Russian].

Batsevych F.S. (2004). Osnovy komunikativnoii lingvistyky [Fundamentals of communicative linguistics]. K.: Akademiia. [in Ukrainian].

Bernadska O.V. (2004). Modeliuvannia sytuatsii profesiinoii diyalnosti u navchanni inozemnoyi movy $u$ vyshchomu navchalnomu zakladi viiskovoho profiliu [Modeling of situations of professional activity in teaching a foreign language in a higher educational institution of military profile]: abstract of thesis ... cand. ped. sciences: 13.00.04 / Kyiv Taras Shevchenko National University. Kyiv. [in Ukrainian].

Dranko A. (2016). Modeliuvannia komunikatyvnykh sytuatsii pry formuvanni hotovnosti maybutnikh pilotiv do profesiynoii vzayemodiyi. Visnyk Natsionalnoyi akademiyi Derzhavnoyi prykordonnoyi sluzhby Ukrayiny. Seriya Pedahohika [Modeling of communicative situations in the formation of readiness of future pilots for professional interaction. Bulletin of the National Academy of the State Border Guard Service of Ukraine. Series Pedagogy]. Vyp. 3. [in Ukrainian].

Fisher T. J. (2016). Cleared to Disconnect? A Study of the Interaction between Airline Pilots and Line Maintenance Engineers: Thesis presented in partial fulfilment of the requirements for the degree of Doctor of Philosophy in Aviation at Massey University, New Zeland.

Kyselova O. B. (2011). Formuvannia kompetentnosti samoosvity u maybutnikh pedahohiv $v$ umovakh informatsiyno-navchalnoho seredovyshcha [Formation of competence of self-education at future teachers in the conditions of information and educational environment]: abstract of thesis ... cand. ped. sciences : 13.00.09 / H.S. Skovoroda Kharkiv National Pedagogical University. Kharkiv. [in Ukrainian].

Navolokova N. P. (2009). Entsyklopediya pedahohichnykh tekhnolohiy ta innovatsiy [Encyclopedia of pedagogical technologies and innovations] Harkiv: Osnova. [in Ukrainian]. 
Plachynda T., Herasymenko L., Pukhalska G., Kryzhevska K. (2019). Using Information Communication Technologies in Professional Training of Future Civil Aviation Pilots. Revista Romaneasca pentru Educatie Multidimensionala. 11(2).

Podolyak L. H., Yurchenko V. I. (2008). Psykholohiya vyshchoyi shkoly: pidruchnyk [Psychology of higher school: textbook]. 2-he vyd. Kyiv : Karavela. [in Ukrainian].

Pometun O. (2007). Entsyklopediia interaktyvnoho navchannia [Encyclopedia of interactive learning]. Kyiv. 2007. [in Ukrainian].

Rozumna T.S. (2012) Pidhotovka maybutnikh uchyteliv humanitarnykh spetsialnostei do orhanizatsiyi interaktyvnoyii vzayemodiyi z uchnyamy [Preparation of future teachers of humanitarian specialties for the organization of interactive interaction with students]: Abstract of Thesis for obtaining Cand. of Ped. Sciences: 13.00.04 / Berdyansk State Pedagogical University. Berdyansk. [in Ukrainian].

Shchukin A. N. (2004). Obucheniye inostrannym yazyvam: Teoriya i praktika: Uchebnoye posobiye dlya prepodavateley $i$ studentov. [Teaching foreign languages: Theory and practice: Textbook for teachers and students.]Moscow: Filomatis. [in Russian].

Tarnopolskyi O. B. (2006). Metodyka navchannia inshomovnoyi movlennievoii diialnosti $u$ vyshchomu movnomu zakladi osvity: navch. posib. [Methods of teaching foreign language speech activity in a higher language institution of education: textbook] K.: Firma «INKOS». [in Ukrainian].

Terletska L. H. (2012). Protses samopiznannia, yoho struktura i rol u stanovlenni osobystosti. Aktualni problemy sotsiolohiyi, psykholohiyi, pedahohiky [The process of self-knowledge, its structure and role in the formation of personality. Actual problems of sociology, psychology, pedagogy]. Vyp. 14. [in Ukrainian].

Tyshchenko O. I. (2016). Samoosvitnia diyalnist vchytelya yak pedahohichna problema. Pedahohika formuvannya tvorchoii osobystosti u vyshchiy i zahalnoosvitnih shkolakh [Self-educational activity of a teacher as a pedagogical problem. Pedagogy of formation of creative personality in higher and general education schools]. Vyp. 47. [in Ukrainian].

Verbitskiy A.A. (1991). Aktivnoye obucheniye v vysshey shkole: kontekstnyy pokhod: metodicheskoye posobiye [Active learning in higher education: a contextual approach: a manual]. M.: Vyssh. shk. [in Russian].

Yakubovska L. P. (2002). Vykorystannia navchalno-rolovykh ihor profesiinoii spriamovanosti $u$ protsesi navchannia inozemnoii movy maybutnikh ofitseriv-prykordonnykiv [The use of educational role-playing games of professional orientation in the process of teaching a foreign language to future border guards officers]: abstract of thesis ... cand. psychol. science: 20.02.02 / Bohdan Khmelnytskyi National Academy of the State Border Guard Service of Ukraine. Khmelnytsky. [in Ukrainian].

Zaniuk S.S. (2002). Psykholohiia motyvatsii: navch. posibnyk. [Psychology of motivation: textbook]. Kyiv: Lybid. [in Ukrainian].

Zimnyaya I.A. (1991). Psikhologiya obucheniya inostrannym yazykam v shkole [Psychology of teaching foreign languages at school]. Moscow: Prosveshceniye. [in Russian]. 